\title{
PENGEMBANGAN PAIN FLOWSHEET BERDASARKAN ELECTRONIC NURSING RECORD SYSTEM
}

\author{
Ni Luh Gede Intan Saraswati ${ }^{1}$ \\ 1.Departermen Keperawatan Medikal Bedah STIKes Wira Medika Bali \\ *Email saraswati622@gmail.com
}

\begin{abstract}
Abstrak
Nyeri merupakan suatu respon tubuh terhadap suatu penyakit maupun suatu tindakan medis. Nyeri yang tidak terkontrol dapat menurunkan kualitas hidup dari pasien. Dokumentasi nyeri merupakan salah bagian penting dalam keperawatan. Melalui dokumentasi dapat tercipta komunikasi yang baik antara tenaga kesehatan, sehingga tercipta pelayananan kesehatan optimal bagi pasien khususnya dalam masalah nyeri. Untuk mendapatkan dokumentasi yang akurat maka dikembangkanlah sebuah program pencatatan nyeri berbasiskan data elektronik. Program ini memiliki fitur yang terintegrasi dari pengkajian, diagnose keperawatan, intervensi keperawatan, dan pengkajian ulang.
\end{abstract}

Kata Kunci : Nyeri, Dokumentasi elektronik, Pain Flowsheet Electronic Nursing Record

Abstract
Pain is body response for disease or medical activity. Uncontrolled pain can be reduce patient quality of life. One of important thing in nursing is pain documentation. Good communication between medical personel created by good documentation so can make optimal service for patient. To obtain accurate documentation, an electronic data-based pain record program was developed. The program features integrated features of assessment, nursing diagnoses, nursing orders, and nursing review.

Keywords: Pain, Electronic Documentation, Pain Flowsheet Electronic Nursing Record

\section{Pendahuluan}

Nyeri merupakan suatu hal yang bersifat obyektif dan personal (Potter \& Perry, 2010). Nyeri merupakan suatu pengalaman yang tidak menyenangkan baik secara sensori maupun emosional akibat adanya suatu ancaman atau kerusakan didalam tubuh. Nyeri dapat digambarkan secara verbal maupun nonverbal. Nyeri dikatakan sebagai tanda vital ke lima dan biasanya muncul sebagai tanda adanya penyakit atau akibat prosedur medis (Goldstein et al., 2013)

Keluhan nyeri menjadi sesuatu yang jarang dikenali, jarang ditangani maupun lambat ditangani selama ini (CEM, 2014), padahal nyeri merupakan suatu prioritas untuk dikenali dan dikurangi pada pasien yang sakit ataupun menderita injury. Hal ini dikarenakan nyeri merupakan suatu gejala yang dapat mempengaruhi kualitas hidup manusia, baik secara fisik, 
emosional, social ekonomi, dan aspek spiritual (Lee, Kim, Jung, \& Song, 2012)

Mengontrol nyeri merupakan salah satu komponen penting dalam asuhan keperawatan (Ward, 2012) dan perawat memiliki tanggung jawab untuk mengontrol secara efektif nyeri pasien, hal ini bukan berarti selalu menggunakan analgesic, tetapi kontrol nyeri yang efektif bersifat holistic, aman, praktis, dan memungkinkan dilakukan oleh pasien (Ward, 2012). Untuk mengontol nyeri, pedoman manajemen nyeri Internasional dan Nasional menetapkan bagaimana memantau dan megelola pasien nyeri dengan rekaman (Lee et al., 2012). Tentunya dalam mengelola pasien nyeri, diperlukan rekaman data-data yang akurat sehingga dibutuhkan suatu dokumentasi yang akurat.

Dokumentasi menjadi salah satu elemen kritis dalam melakukan manajemen nyeri karena dalam dokumentasi terdapat data permanen mengenai pengkajian, terapi, dan respon pasien(Samuels, 2012). Dokumentasi menjadi salah satu bentuk komunikasi antara petugas kesehatan, dapat membantu praktisi kesehatan untuk mendapatkan informasi obyektif yang dibutuhkan secara berkesinambungan (Samuels \& Kritter, 2011). Salah satu upaya yang dilakukan untuk menghasilkan informasi yang akurat mengenai nyeri, maka dikembangkanlah sebuah sistem manajemen nyeri yang terintegrasi untuk staf kesehatan yang berbasiskan data elektronik yaitu pain flowsheet based on electronic nursing record (Lee et al., 2012).

Dokumentasi elektronik merupakan salah satu bentuk pengembangan dokumentasi dari yang bersifat tradisional (menggunakan kertas) menjadi sebuah dokumentasi berbasis teknologi elektronik yang pada tahun 2009 telah dengan cepat menggantikan fungsi kertas dokumentasi di Amerika(Samuels \& Kritter, 2011). Dokumentasi menggunakan kertas memiliki beberapa kelemahan antara lain, terkadang sulit terbaca, sering terjadinya duplikasi, tenaga kesehatan lalai atau lupa mencatat, 
untuk itu dokumentasi elektronik dijanjikan menyediakan keuntungankeuntungan salah satunya efisien dan efektif dalam waktu sehingga dapat

\section{Kajian Literatur}

Pain Flowsheet Nursing record merupakan salah satu pengembangan dokumentasi elektronik (electronical medical record), yang dibutuhkan sebagai alat komunikasi diantara para tenaga kesehatan sehingga dapat menghasilkan kontrol nyeri yang efektif. Fokus studi ini adalah bagaimana dapat mengintegrasikan setiap data dan berusaha menghindari adanya duplikasi dokumentasi. Pain Flowsheet nursing record dikembangkan dalam lingkungan C\#.NET dan Windows XP dengan Microsoft Framework v. 4.x dan MS SQL2008 untuk DBMS. Dalam pengembangan bahasa digunakan MS Visual studio 2008 dan aplikasi ini dijalankan menggunakan program Windows $\mathrm{XP}, \mathrm{Win} 7$ environment.

Sistem ini didesain melalui dalil yang mengikuti langkahlangkah berupa (1) analisis catatan keperawatan yang terkait dengan meningkatkan kualitas dalam pelayanan kesehatan. (Mantas, Zikos, \& Diomidous, 2013)

keluhan nyeri, (2) Memilih tujuan dan diagnosis keperawatan nyeri untuk terintegrasi dengan sistem manajemen (3) menyaring kegiatan pengkajian keperawatan yang terkait nyeri dan memilih intervensi nyeri untuk ditampilkan dalam pain flowsheet (4) Mendesain prototype pain flowsheet (5) dan mengaplikasikan pain flowsheet. Berdasarkan tahapan-tahapan tersebut maka dihasilkan pain flowsheet yang tersusun dari fungsi administrasi yang berhubungan dengan pengkajian nyeri dan aktivitas perawatan professional. Melalu proses analisis catatan keperawatan yang terkait dengan nyeri diambil dan dikumpulkanlah data mengenai aktivitas keperawatan, tujuan keperawatan, diagnosis keperawatan, dan intervensi keperawatan melalui sistem MS SQL dan CDW. Dalam memilih target tindakan keperawatan dan diagnosis keperawatan sistem manajemen melakukan simulasi, mengatur ulang 
item dan mengevaluasi pemanfaatan klinis beberapa kali menurut prototype layar, dan akhirnya memilih "Nyeri Akut", "Nyeri Kronis" sebagai diagnosa keperawatan dan menjadikan "PrePost Operation Care", "Pre-Post Examination Care", "Visiting ER" sebagai target tindakan keperawatan. Pada proses ketiga didapatkan hasil dalam proses pengkajian keperawatan, maka hal yang harus dikaji berupa lokasi, kekuatan nyeri, adanya suatu alat evaluasi nyeri (seperti Numerical Pain Intensity Scale), pola dan karakteristik nyeri, dan gejala-gejala yang menyertai. Dalam mengontrol nyeri maka dalam dokumentasi disediakan pilihan berupa terapi non obat atau terapi obat-obatan dengan informasi mengenai bahan dan isi terapi, waktu pemberian, adanya data pemberi informasi dan pendengar, level pengontrolan nyeri yang ingin dicapai, dosis terapi, frekuensi pemberian beserta tujuan pemberian terapi.

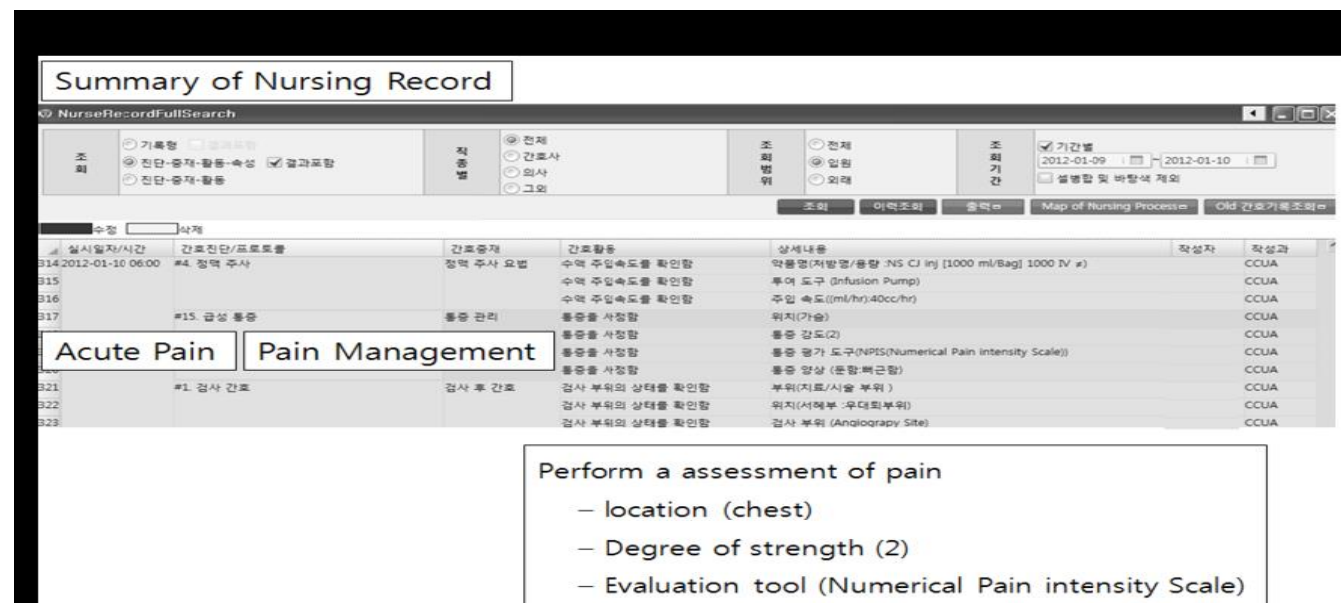

Gambar 1. Contoh catatan keperawatan dan target tindakan keperawatan

Hasil keempat adalah bentuk prototype pain flowsheet yang terdiri dari sumbu $X$ yang berfungsi sebagai tanggal dan waktu dimana perawat mengakses dan memonitor keluhan nyeri pasien. Sumbu Y menunjukkan derajat kekuatan nyeri yang dirasakan pasien. Contoh prototype dapat dilihat pada gambar 2 . 


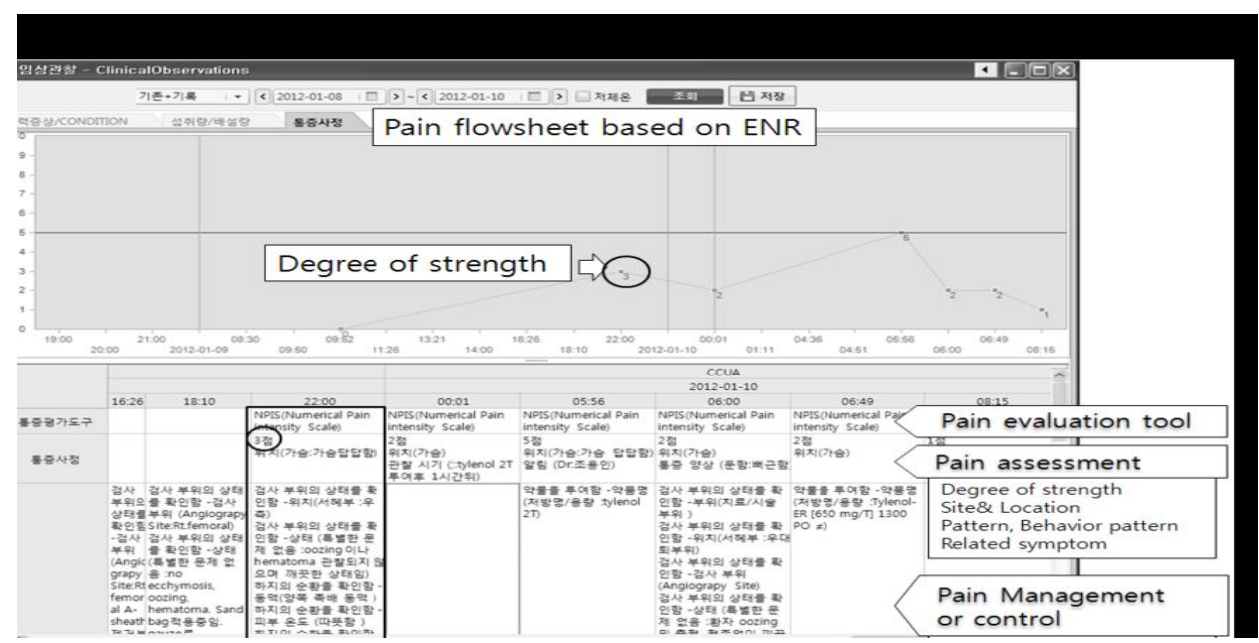

Gambar 2. Prototype pain flowsheet electronical nursing record

Dalam

proses

pengaplikasiannya, painflowsheet

digunakan layaknya seperti catatan

observasi klinis dan observasi cairan

\section{Pembahasan}

Nyeri direkomendasikan sebagai tanda vital kelima dan biasanya muncul sebagai suatu tanda ketika adanya penyakit maupun akibat dari suatu tindakan medis (Goldstein et al., 2013). Dilaporkan $50-80 \%$ pasien mengeluhkan nyeri sedang sampai berat pasca operasi (Goldstein et al., 2013). Nyeri mempengaruhi kualitas hidup seseorang, nyeri pasca operasi yang tidak tertangani dengan baik akan menghambat penyembuhan, meningkatkan morbiditas, memperpanjang hari rawat, dan nyeri akut dapat berubah menjadi nyeri kronis (Zaslansky et al., 2014), untuk itu nyeri kronis maupun nyeri akut harus dapat dikontrol dengan baik.

Dalam upaya mengontrol nyeri, diperlukan sebuah pencatatan data yang akurat yang meliputi pengkajian, diagnose keperawatan, intervensi keperawatan, beserta pengkajian ulang setelah diberikan intervensi. Pencatatan atau yang sering disebut dengan dokumentasi merupakan suatu elemen yang penting, karena melalui dokumentasi antara tenaga kesehatan dapat saling berkomunikasi untuk memberikan perawatan yang tepat bagi pasien. Dokumentasi harus ditulis untuk mencerminkan suatu penilaian klinis, 
disajikan secara logis, dan berurutan. Hal ini sesuai dengan kebutuhan perawatan nyeri yang harus berdasarkan suatu penilaian sebagai suatu mekanisme untuk mengidentifikasi kebutuhan akan nyeri serta perawatan lanjutan (Samuels \& Kritter, 2011). Dokumentasi juga harus mencatat variasi dalam kebutuhan keperawatan dan memenuhi kebutuhan pasien .

Untuk itu diperlukan suatu sistem informasi dokumentasi yang mudah diakses dan handal (Samuels \& Kritter, 2011), maka dikembangkanlah sistem pain flowsheet nursing record, yang berbasiskan tekhnologi pencatatan elektronik yang bisa diaplikasikan pada sistem windows XP ataupun windows 7. Sistem ini dikembangkan sebagai bentuk dokumentasi nyeri pasien.

Kelebihan dari penggunaan electronic nursing record ini adalah dapat menurunkan tingkat kesalahan (error), dapat meningkatkan pelayanan keperawatan dan dapat menurunkan biaya. Manfaat ini dapat dimaksimalkan

dengan menggunakan standar terminologi keperawatan sehingga dapat meningkatkan kualitas data, penyebaran data, dan pengambil keputusan (Park, Min, Jeon, \& Chung, 2012). Pain flowsheet electronical nursing record telah menyediakan fitur-fitur yang terdiri dari penilaian atau pengkajian nyeri, diagnose keperawatan nyeri, intervensi dari nyeri dan adanya evaluasi ulang dari respon pasien serta adanya pencatatan waktu sehingga program ini sudah sesuai dengan yang diamanatkan dalam Joint Commission Akreditasi Healthcare, 2009 dalam Samuels, 2012) dimana penilaian standar nyeri terdiri dari penilaian awal yang komprehensif, berkelanjutan dan rutin. Selain itu Samuel, 2012 menyatakan pengembangan suatu pencatatan mengenai nyeri harus menggambarkan keadaan klinis yang ada, menggabungkan penilaian nyeri, intervensi, dan pengkajian ulang sehingga memungkinkan gambaran nyeri dan intervensi yang lebih dipahami dari perawatan yang diberikan. Penelitian yang dilakukan 
oleh Samuel \& Kritter, 2011 menyatakan bahwa setelah diberikan intervensi menggunakan catatan elektronik (electronical medical record) didapatkan peningkatan hasil yang signifikan dari segi kualitas dan kuantitas dalam proses dokumentasi nyeri yang dilakukan oleh perawat.

Program pain flowsheet electronical nursing record dapat dijalankan dalam program XP maupun Windows 7 sehingga ini merupakan suatu kemudahan karena saat ini program-program inilah yang beredar dipasaran,. Program ini menggunakan MySQL dan MySQL dapat berjalan stabil pada berbagai sistem operasi seperti Windows, Linux, FreeBSD, Mac OS X Server, Solaris, Amiga serta MySQL memiliki beberapa level keamanan dan mampu menangani basis data skala besar (Gunawan Susanto, 2012) Selain itu proses perubahan dokumentasi tradisonal (dengan menggunakan kertas) menjadi menggunakan media elektronik, menjadi suatu tantangan dan diperlukan suatu kemampuan para staf untuk mengaplikasikan program tersebut (Samuels \& Kritter, 2011)

\section{Simpulan}

Pengembangan pain flowsheet electronical nursing record, merupakan salah satu upaya yang dilakukan untuk meningkatkan dokumentasi keperawatan bagi keluhan nyeri pasien. Perbaikan dalam suatu proses dokumentasi akan memperbaiki komunikasi antara tenaga kesehatan sehingga akan memperbaiki proses pelayanan keperawatan pada pasien dengan keluhan nyeri. Nyeri yang terkontrol dengan baik akan meningkatkan kualitas hidup pasien serta dapat menurunkan lama hari rawat pasien.

\section{Rekomendasi}

Nyeri sebagai salah satu tanda vital kelima bagi pasien, merupakan hal yang tidak bisa diabaikan, dan perlu mendapatkan penganganan dengan segera. Diperlukan suatu pendekomentasian yang efektif mengenai nyeri sehingga tercapainya pelayanan yang optimal bagi pasien. Pemanfaatan electronical medical record dalam hal ini adalah aplikasi pain flowsheet electronical nursing record memberikan keuntungan pada perawat maupun tenaga kesehatan 
lainya yaitu berupa data yang terintegrasi dan terhindarnya duplikasi dokumentasi. Program ini telah memiliki fitur pengkajian yang didalamnya terdapat lokasi, kekuatan nyeri, adanya suatu alat evaluasi nyeri (seperti Numerical Pain Intensity Scale), pola dan karakteristik nyeri, dan gejala-gejala yang menyertai, pilihan terapi juga telah disesuaikan dengan pengkajian dan diagnose keperawatan yang didapat. Dokumentasi kesehatan atau dokumentasi keperawatan berbasis elekstronik yang merupakan bagian dari pengembangan teknologi informasi kesehatan bukan merupakan hal baru bahkan di Amerika sejak tahun 2004 telah terjadi peningkatan pengaplikasian teknologi sistem informasi oleh care provider ((Hing \& Hsiao, 2010), namun hal ini merupakan suatu tantangan bagi tenaga keperawatan untuk dapat menyesuaikan diri serta dalam mengaplikasikannya, diperlukan proses latihan (Samuels \& Kritter, 2011). Sistem nursing electronical record memberikan implikasi yang positif dalam dunia keperawatan karena dapat membantu meningkatkan kualitas data, penyebaran data, dan pengambil keputusan (Park et al., 2012). Di Indonesia adopsi sistem teknologi kesehatan secara tersirat telah ditunjukan dengan adanya Permenkes

No.269/Menkes/PER/III/2008

dimana Bab II ayat 2 pasal 1 permenkes telah menyatakan bahwa dokumentasi harus dibuat secara tertulis, lengkap dan jelas atau secara elektronik. Adanya permenkes tersebut menjadikan dunia keperawatan Indonesia harus mampu dalam menerapkan suatu dokumentasi elektronik yang bertujuan untuk meningkatkan pelayanan keperawatan. Penerapan Pain Flowsheet Electronical Medical Record diharapkan dapat membantu dunia keperawatan Indonesia untuk meningkatkan kualitas asuhan keperawatan pada pasien. Sistem ini juga masih perlu dikembangkan untuk dapat meningkatkan kefektifan manajemen nyeri, karena nyeri pada pasien memiliki berbagai macam karakteristik yang berhubungan dengan berbagai faktor dan deskripsi mengenai intervensi harus dapat 
terintegrasi untuk dapat memaparkan apa yang seharusnya kita lakukan (Lee et al., 2012).

\section{Referensi}

CEM. (2014). The Collage Emergency Medicine Best Practice Guideline Manajemen Pain in Adults. Diakses dari: http//: rcem.ac.uk

Goldstein, D. H., Phelan, R., Wilson, R., Ross-White, A., Vandenkerkhof, E. G., Penning, J. P., \& Jaeger, M. (2013). Brief review: Adoption of electronic medical records to enhance acute pain management. Canadian Journal of Anaesthesia = Journal Canadien D'anesthesie, $\quad$ 164-179. http://doi.org/10.1007/s12630013-0069-6

Gunawan Susanto, S. (2012). Sistem Informasi Rekam Medis Pada Rumah Sakit Umum Daerah ( Rsud ) Pacitan Berbasis Web

Base. Speed - Sentra Penelitian Engineering Dan Edukasi, 9(3), 40-46.
Hing, E., \& Hsiao, C.-J. (2010). Electronic medical record use by office-based physicians and their practices: United States, 2007. National Health Statistics Reports, (23), 1-11.

Lee, J. M., Kim, Y. A., Jung, H., \& Song, M. (2012). Development of Pain flowsheet based on electronic nursing record system. Studies in Health Technology and Informatics, 180, 1065-1069. http://doi.org/10.3233/978-161499-101-4-1065

Mantas, J., Zikos, D., \& Diomidous, M. (2013). Exploring the potential of an electronic documentation system to reduce length of stay. Studies in Health Technology and Informatics, 192(1-2), 1179. http://doi.org/10.3233/978-161499-289-9-1179 
Park, H. A., Min, Y. H., Jeon, E., \& Chung, E. (2012). Integration of Evidence into a Detailed Clinical Model-based Electronic Nursing Record System. Healthcare Informatics Research, 18(2), $136-144$.

http://doi.org/10.4258/hir.2012. 18.2.136

Potter \& Perry.(2010).Fundamental Of Nursing.Jakarta:Salemba Medika

Samuels, J. G. (2012). Abstracting pain management documentation from the electronic medical record: Comparison of three hospitals. Applied Nursing Research, 25(2), 89-94.

http://doi.org/10.1016/j.apnr.20 10.05.001

Samuels, J. G., \& Kritter, D. (2011). Pain Management Documentation Analyzing One Hospital , s Computerized
Clinical Records, 29(9), 512518.

http://doi.org/10.1097/NCN.0b 013e31821a1582

Ward, Jennifer.(2012).Nurse's Role in Pain Management. Diakses dari: http//:NurseTogether.com Zaslansky, R., Rothaug, J., Chapman, R. C., Backström, R., Brill, S., Engel, C., ... Meissner, W. (2014). PAIN OUT: An international acute pain registry supporting clinicians in decision making and in quality improvement activities. Journal of Evaluation in Clinical Practice, 20(1), 1090-1098. http://doi.org/10.1111/jep.1220 5 